\title{
Maintaining Sustainable Practices in SMEs: Insights from Sweden
}

\author{
Desislava Tsvetkova ${ }^{1, *}$, Emma Bengtsson ${ }^{2, *}$ and Susanne Durst ${ }^{3, *}$ (D) \\ 1 Independent Researcher, 2300 Copenhagen, Denmark \\ 2 Independent Researcher, 30578 Kvibille, Sweden \\ 3 Department of Business Administration, Tallinn University of Technology, 19086 Tallinn, Estonia \\ * Correspondence: desi.i.tsvetkova@gmail.com (D.T.); emma.bengtsson@bahnhof.se (E.B.); \\ susanne.durst@taltech.ee (S.D.)
}

Received: 12 November 2020; Accepted: 3 December 2020; Published: 8 December 2020

check for updates

\begin{abstract}
By addressing the scarce knowledge of sustainability practices in small and medium-sized enterprises (SMEs), the purpose of the paper is to identify drivers for the maintenance of such practices and their extent. Based on a series of semi-structured interviews conducted with small Swedish firms, our findings reveal certain external (i.e., suppliers and customers) and internal (i.e., employees, organizational culture, and competitive advantage) factors that are strongly linked to the maintenance of sustainability practices. Apart from these, the longevity of the business was identified as an additional sustainability maintenance factor. This factor has not been discussed previously in the literature, so given its strength, we suggest to have it stand separately. The findings further indicate that Swedish SMEs are not limited by size concerning their sustainability practices but they are consciously working on progressing in their efforts. Furthermore, drawing on our findings we provide practical implications that will help business owners', managers, and policymakers to better enable sustainability practices.
\end{abstract}

Keywords: sustainability; sustainable practice; SMEs; drivers; maintenance

\section{Introduction}

The need to contribute to society, both socially and environmentally, as well as maintaining financial profitability has slowly turned into a focal point for businesses. This concept labeled sustainability has long been related by scholars to the triple bottom line (TBL) aiming to synchronize the social, environmental, and financial outcomes of a business [1]. On that note, in this paper sustainability and sustainable development are to be understood as having synonymous meaning.

Sustainability has primarily been studied with a focus on large enterprises, while research on small and medium-sized enterprises (SMEs) has received little attention [2,3]. This is rather surprising given the SMEs' key role in the global economy [4]. In Sweden, for example, they account for $99.9 \%$ of all enterprises and contribute around $40 \%$ of the value-added [5]. Also, based on the SMEs' collective impact on the economic, environmental, and social areas, they are fundamental to advancing the Sustainable Development Goals (SDGs) established by the United Nations (UN) [6].

Research focusing solely on SMEs is scarce and rather fragmented, thus we see a pressing need for more rigorous research focusing on SMEs, and their sustainability practices in particular. As advancements regarding the SDGs call for long-term efforts, so do sustainability practices [7], which can prove difficult as they are often abandoned not long after adoption [2]. While there is research that has been dedicated to investigating the drivers for the adoption of sustainability practices in SMEs, the maintenance component of these practices has been neglected. For instance, positive relations have been found between these drivers and the adoption of sustainability practices: access to new markets 
and gaining competitive advantage [8,9], positive brand image and increased customer base [10], and internal social relations with employees [11,12].

More precisely the interest is in studying Swedish SMEs since Swedish businesses are among the top rankings of the Global sustainability competitive index [13]. Moreover, we consider it appropriate to investigate the extent of the exercised sustainability practices (i.e., the type of sustainability engagement) found in Swedish SMEs. This would allow us to investigate the phenomenon by using the typology of business sustainability proposed by Dyllick and Muff [14], to find out whether there are already some small firms that can be labeled as truly sustainable businesses, also known as "Business Sustainability 3.0".

Against this background, the purpose of this paper is to identify the external and internal drivers for maintaining sustainability practices and to investigate the extent of these practices in Swedish SMEs. Based on that, the two main research questions we posed are: "What are the external and internal drivers for the maintenance of sustainability practices in Swedish SMEs?" and "How far have Swedish SMEs come in their sustainability practices"?

The paper is structured as follows. In the next section, we outline the literature relevant to the topic. Following that is a section that presents and describes the methodology chosen. Then, the findings of the study are presented. This is followed by a discussion of the study's implications, limitations, and future research agenda. The paper terminates with a conclusion section.

\section{Literature}

\subsection{Defining Sustainability}

When discussing the topic of sustainability, researchers have been advised to explicitly define the concept based on their personal perspective [15]. Thus, the paper will further investigate the phenomenon in regards to its three pillars, which are set to derive from the TBL coined by John Elkington in the late 1990s [16]. From a business perspective developing sustainability would imply that prosperity should not come at the cost of harming the environment or disregard and exploitation for humans in any form.

\subsection{Defining Sustainability Practices}

In Sweden, sustainable business is defined as having "active concern for the environment, human rights, work requirements, anti-corruption, business ethics, gender equality and diversity" [17] (p. 18). In this regard, Dyllick and Muff [14] propose a typology of business sustainability depending on the exercised level of development. Ideally, this should provoke businesses to change the game, by turning from an inside-out approach (i.e., how businesses are contributing to none or some sustainability issues) to an outside-in (i.e., how businesses are contributing effectively to solving global challenges). The typology uses the Business-as-usual: The Current Economic Paradigm as a starting point: Business Sustainability 1.0: Refined Shareholder Value Management, Business Sustainability 2.0: Managing for the Triple Bottom Line, Business Sustainability 3.0: Truly Sustainable Business [14]. Based on the authors' typology proposal we have developed a matrix of the stages of sustainable development to serve as a guiding line for the empirical testing of the typology (Figure 1).

To properly distinguish between the four quadrants and their meaning, the capitalist model is the starting point, where sustainability is not considered as businesses' responsibility, i.e., economic prosperity is the pure focus. Following is the second quadrant, which we named situational development, due to the businesses' practice of shifting focus towards sustainability when potential economic outcomes depend on it. Within this type, it is also considered relevant to adopt such a strategy, or initiatives, based on pressure from valued stakeholders.

Already within the third quadrant, incremental development, businesses are deliberately developing their sustainability practices. These practices are meant to incorporate social issues, environmental concerns, and economic prosperity, or the so-called TBL in their daily routines. The last 
quadrant, radical development, is considered by Dyllick and Muff [14] to be the game-changer, where sustainability is not only implemented but is considered as a priority for businesses. On that note, it does not mean that economic prosperity is forgotten, but rather that by focusing on advancing the UN's SDGs, financial viability will follow as a result.

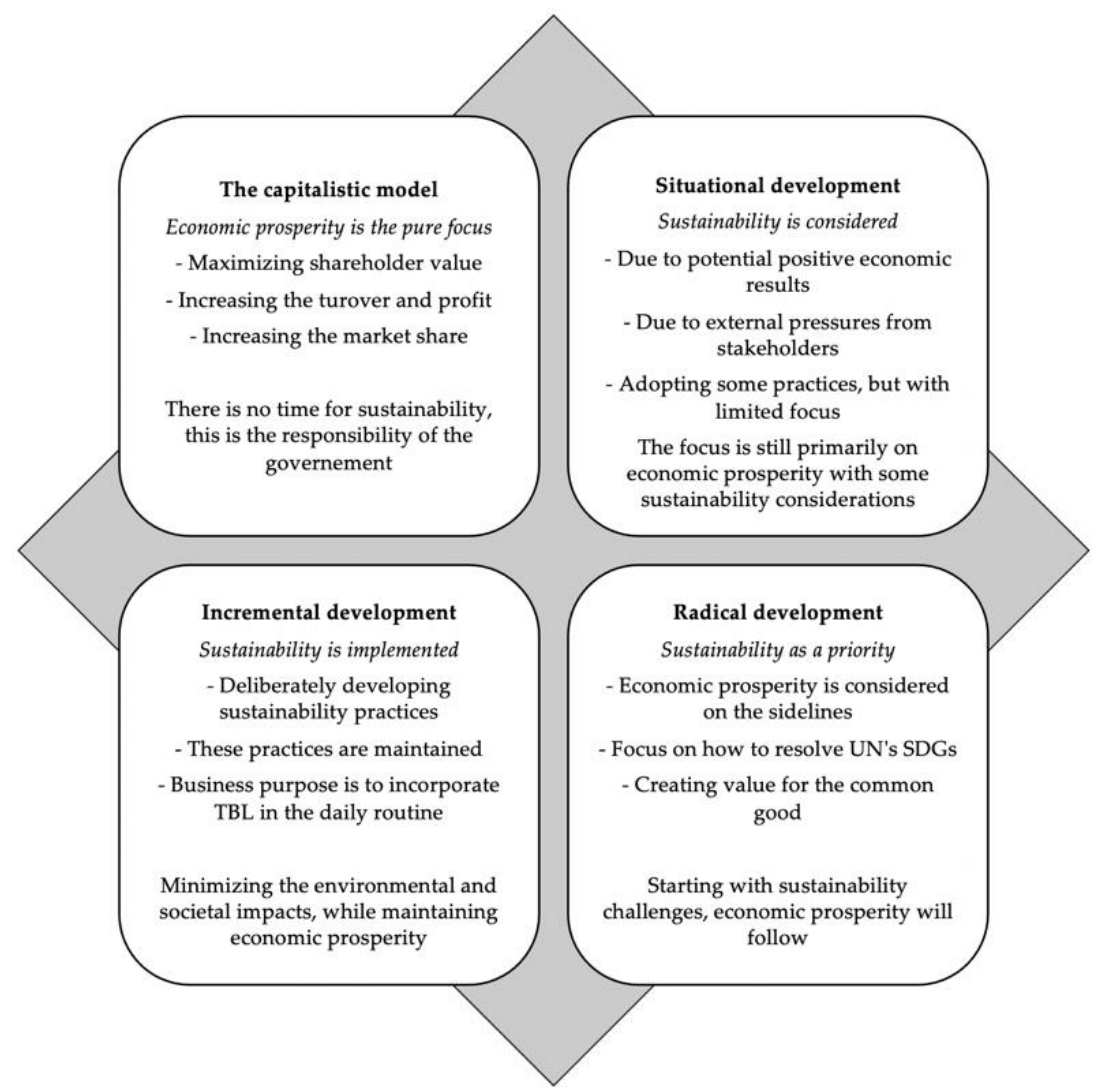

Figure 1. Matrix of the stages of sustainable development, own elaboration based on Dyllick and Muff [14].

\subsection{Drivers for Sustainable Development}

Due to the lack of research on the drivers for maintenance in regards to SMEs, inspiration will be drawn from the literature on adopting sustainability. It is known that external drivers affect the internal ones and both will influence the adoption and development of sustainable innovation [18], therefore the discussion will start from the former and move to the latter. The factors within each dimension derived from a systematic literature review of 44 articles in the period 1987-2018, on drivers for sustainability practices and SMEs conducted by Yadav, Gupta, Rani, and Rawat [19].

\subsubsection{External Factors}

\section{Government}

It has been argued that governments are a strong driver when it comes to sustainability engagement from firms in the Scandinavian region [20]. Hence, it is not surprising that the Swedish government has been an active player in promoting sustainability practices among society and businesses. A report published by the UN [21] revealed the extensive efforts Sweden has put towards contributing to the execution of Agenda 21 and 2030 Agenda. 
Networks and Alliances

Due to SMEs' restrained resources, these are considered to have a positive attitude towards participating in local networks aiming to collectively solve ecological and societal problems [22]. In Sweden, there are different networks such as the Sustainable Business Hub, TEM, and CSR VästSverige, which are promoting innovation and sustainable business development.

\section{Competitors}

Due to hyper-competition and globalization, companies may change their products after studying the offering of competitors worldwide, thus this can be considered as a driver for engaging in sustainability practices, such a positive link has been found in a study conducted by Lee and Klassen [23]. Swedish companies might be considered highly susceptible, due to the geographical limits of their domestic market. Therefore, expanding operations to international markets might necessitate the development of sustainable practice.

Suppliers

Many SMEs are a part of the global supply chains of large corporations, thus greening the supply chains has been argued to be more important for internationalized firms than domestically operating ones $[23,24]$. The majority of large firms have procurement policies and criteria, which have to be met before working relations are established. Hence, even domestically operating SMEs working with large corporations can be pressured into enforcing sustainability practices in their operations.

\section{Customers}

Depending on the customer segments, SMEs' behavior towards engaging in sustainability practices might be influenced. Furthermore, a positive relationship has been found between the demand for green offerings and SMEs focusing on sustainability practices $[23,25]$.

\section{Community Surroundings}

Public demand for such practices, deriving from high levels of community participation, can also increase the engagement levels of SMEs [9]. In Sweden, there are several environmental groups pressuring politicians and businesses towards implementing stricter sustainability practices.

\subsubsection{Internal Factors}

\section{Employees}

Employees' involvement, in sustainable practices, helps to implement it successfully [26]. Furthermore, researchers have found that employees do influence SMEs' work, especially towards sustainability. For example, Zhang, Bi, and Liu [27] found that demand from employees has a high impact when it comes to SMEs' adoption of environmental practices. Another study came across the fact that employees' working conditions have a positive effect on SMEs and their investments in environmental issues [28].

\section{Organizational Culture}

Researchers argue that organizational culture has a high impact, thus it is considered a key driver for sustainability practices when it comes to SMEs $[29,30]$. This can be explained by the fact that decision-making, in smaller enterprises, often relies on owner-managers' personality and characteristics, rather than economic conditions [31,32]. 
Brand Image and Reputation

Corporate image is another key driver for sustainability that has received a lot of attention. Agan, Acar, and Borodin [33] found that 'Expected Soft Benefits', such as corporate image and brand name are the strongest drivers of environmental activities for SMEs. It has also been argued that SMEs apply environmental activities to gain a better green public image, demonstrate environmental stewardship, and green brand image $[29,31]$.

\section{Competitive Advantages and Strategic Intent}

Gadenne, Kennedy, and McKeiver [34] found that SME owner-managers are adopting sustainability in their organizations with cost-saving intentions. However, this transformation (i.e., build greener organizations) often demands investments in technology developments, employee training, and a reconstruction of the organizational structure [35], which can be difficult for SMEs to take on. On the other hand, Battisti and Perry [31] argue that investments in environmental sustainability can be perceived as beneficial. Still, according to Sáez-Martínez, Díaz-García, and González-Moreno [25] SMEs are focusing on environmental responsibility mainly due to strategic intent.

Size of the Firm

According to a study conducted by Reyes-Rodríguez, Ulhøi, and Madsen [36], the size of the firm is seen as an important driver for SMEs regarding their environmental initiatives, especially their greening processes [37]. Thus, small firms seem to be the enterprises that engage the most in greening processes [37]. However, Johnson [38] states that bigger SMEs are more likely to adopt sustainability management tools to manage these processes.

\section{Methods}

Given the exploratory nature of the study, a qualitative research approach was chosen [39]. This research approach allows researchers to get close to participants and their thinking to scrutinize and explore the entire research problem [40]. Given the study's research aim and questions posed this was considered relevant. More precisely for data collection, semi-structured interviews were found to be the most suitable option for this study. An interview guide supported the execution of interviews, where the questions were created by ourselves since previously used ones could not be identified. The questions were divided into four categories: current sustainability practices, drivers for adopting sustainability practices, drivers for maintaining sustainability practices, and level of commitment and progress. Examples of questions are: "How is the company addressing social and environmental issues?", "What were the factors that influenced the company's approach to sustainability?", "What are the factors that make you maintain the company's sustainability practice?", and "Please describe your progress with regard to the company's sustainable development. Has it changed from the beginning to now?"

Extraordinary circumstances in 2020 (i.e., COVID-19) made the execution of face-to-face interviews impossible. However, the interviews were still conducted in a synchronous environment via online platforms, allowing real-time, back-and-forth communication [41]. This gave us and the participants an experience almost similar to a physical face-to-face meeting. It further enhanced the pool of possible interviewees, as it could include geographically dispersed potential participants.

In regards to sampling, it was based on a purposive sampling technique, i.e., criterion sampling, as we wanted a sample consisting of strategically selected objects. To ensure that the firms were relevant a list of the criteria was created. First, the participating firms had to be commercial companies. Second, they needed to be classified as SMEs according to the definition stated by the European Commission [42], which is to have less than 250 employees and that the enterprise should have an annual turnover of no more than EUR 50 million or a balance sheet total of EUR 43 million. Furthermore, another criterion was that the participating firms should have fallen into the category of Enterprise 
Type 1 (i.e., family-owned business/owner-manager operated) or Type 2 (i.e., manager operated with a board of directors), where the owner-manager or the manager is responsible for both the short-term and long-term strategic decisions. Last but not least, a firm was considered relevant, only if it had been engaging in some type of sustainability before contact. The objects' eligibility was investigated via online desk research, meaning that several online platforms were used for ensuring the criteria were met before the initial contact.

In total nine interviews were held (see Table 1), where each company apart from B and $\mathrm{H}$ are manufacturers. The duration of the interviews varied between 30-60 min depending on the specific situation. The interviewees were either the CEOs of the companies or the employees responsible for the sustainability issues in the respective firm, thus ensuring that these could sufficiently respond to the interview questions. The firms were mainly located in the southern regions of Sweden since we found most of them through networks focusing on CSR for companies situated in the west of Sweden. The interviews were conducted in 2020 between March and May.

At the beginning of each interview, the purpose and the researchers were presented. Confirmation of the interviewee's anonymity and approval for recording the conversation was given before continuing. The interviewees were encouraged to express their genuine opinion and to share their company's specific situation in no particular order, thus not specifically following the numbering of the questions in the guide. This further contributed to a better flow in the discussions, while at the same it revealed some more in-depth thoughts and information. Furthermore, we tried to keep the influence of existing knowledge at the minimum to be open to the ideas and insights from the interviewees [43].

It has been argued that qualitative researchers should conduct their analysis rigorously and systematically to increase the trustworthiness of their data [44], as otherwise evaluating the quality of it proves difficult [45]. Figure 2 outlines the guiding technique proposed by Nowell, Norris, White, and Moules [46], which was followed for analyzing the data.

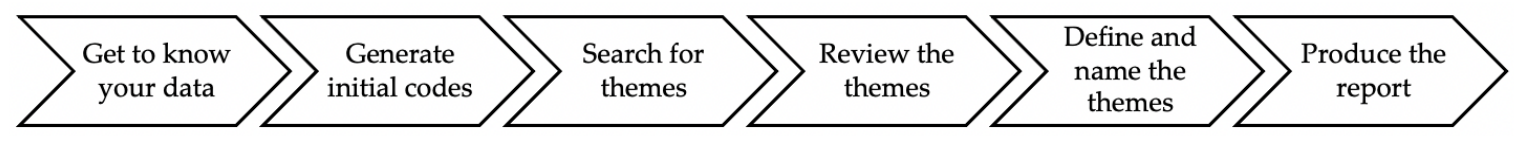

Figure 2. The process of conducting thematic analysis by Nowell et al. [46].

To get to know our data we started to label the recordings with the company name and their respective letter (i.e., representing the case from which the data came from), the name and title of the interviewee, as well as the date and time when the interviews took place. We transcribed all recordings manually, hence giving us rather detailed and in-depth knowledge of the data since the process required multiple listening. After the recordings were transcribed, the transcripts were sent to the interviewees, to ensure that their answers were not misunderstood, and to allow them to revise them. Once the transcripts were approved, we started the process of analyzing the data by generating initial codes. We created a template with the codes we found most appropriate, i.e., general opinion, progress, activity, longevity, and drivers.

After the coding process was finalized, we started to sort through these and create relevant themes, such as external drivers, internal drivers, and development. These were developed based on the information provided by the participating SMEs, helping us to find patterns among the data sets. Furthermore, it became apparent that some of the codes and their subsequent themes needed to be revised. The main reason for revising the themes was that these were in some places too close to each other (or repetitive), thus these could be unified into one theme. On the other hand, in some instances, new themes were developed, as the data sets were incorporating more than one code. As we identified the story for each theme, the final set was presented under headings with attention paid to differentiating between the two research questions, as well as to present the themes within them. 
Table 1. Information about the participating firms.

\begin{tabular}{|c|c|c|c|c|c|c|c|}
\hline Company & Date of the Interview & Interviewee & $\begin{array}{c}\text { Number of } \\
\text { Employees and Type }\end{array}$ & Duration of SD & Customer Segments & Markets & Suppliers \\
\hline A & 24 March 2020 & The CEO/Sales Director & $\begin{array}{c}28 \\
\text { Type } 2\end{array}$ & More than 2 years & Public and B2B & Domestic and international in the EU & Within the EU \\
\hline $\mathrm{B}(1-3)^{*}$ & 30 March 2020 & The Sustainability Coordinator & $\begin{array}{c}79 \\
\text { Type } 2\end{array}$ & Extended period & Public and $\mathrm{B} 2 \mathrm{~B}$ & Primarily domestic and the Nordic region & None \\
\hline B1 & & & 47 & & & & \\
\hline B2 & & & 11 & & & & \\
\hline C & 2 April 2020 & $\begin{array}{l}\text { The CEO, and the } \\
\text { Sustainability Coordinator }\end{array}$ & $\begin{array}{l}18 \\
35 \\
\text { Type } 1\end{array}$ & Roughly 7 years & $\mathrm{B} 2 \mathrm{~B}$ and B2C (only a few items) & Nordic region and the EU & Outside the EU \\
\hline $\mathrm{D}$ & 3 April 2020 & $\begin{array}{l}\text { The Environmental and } \\
\text { Sustainability Coordinator }\end{array}$ & $\begin{array}{c}93 \\
\text { Type } 2\end{array}$ & Roughly 1.5 years & Public and B2B & Primarily the Nordic region and some in Europe & $\begin{array}{l}\text { Primarily Sweden and } \\
\text { some outside the EU }\end{array}$ \\
\hline E & 15 April 2020 & The Quality Manager & $\begin{array}{l}107 \\
\text { Type } 1\end{array}$ & Roughly 7 years & $\mathrm{B} 2 \mathrm{~B}$ and $\mathrm{B} 2 \mathrm{C}$ & Domestic and international EU and non-EU & Outside the EU \\
\hline $\mathrm{F}$ & 15 April 2020 & The CEO & $\begin{array}{l}100 \\
\text { Type } 1\end{array}$ & Extended period & Public and B2B & Domestic and international EU and non-EU & Within and outside the EU \\
\hline G & 6 May 2020 & The Sustainability Coordinator & $\begin{array}{c}120 \\
\text { Type } 1\end{array}$ & Extended period & В2В & Primarily international within the EU and non-EU & Within the EU \\
\hline $\mathrm{H}$ & 8 May 2020 & The Sustainability Manager & $\begin{array}{c}180 \\
\text { Type } 2\end{array}$ & Extended period & Public, B2B, and B2C & Primarily domestic & Within and outside the EU \\
\hline I & 11 May 2020 & The CEO & $\begin{array}{c}32 \\
\text { Type } 1\end{array}$ & Roughly 8 years & Public and B2B & Primarily EU and some non-EU & Within the EU \\
\hline
\end{tabular}

* Company B has three subdivisions, where sustainability practices differ. However, their development is directed by one sustainability coordinator, hence company B represents the headquarters where the administration is located, B1, B2 and B3 are the subdivisions. 
King [47] urges researchers to include direct quotes from participants, which will further enhance the merit of the analysis [45]. We, therefore, included the most relevant quotes from the participants, so the reader can get an idea about the original text. Moreover, this has allowed us to theorize the meaning of these and their possible implications concerning the theoretical foundation (i.e., whether strong or weak connection). On the other hand, the findings were also used as an opportunity to challenge existing findings, and to add to the literature body on the subject.

\section{Findings and Discussion}

\subsection{The Participating SMEs' Perception of Sustainability Engagement}

When asked to clarify how they are addressing their internal and external social sustainability engagement, all companies had difficulties to reflect upon that. Table 2 highlights some of the statements received.

Table 2. Example quotes from the interviews.

\begin{tabular}{|c|c|c|}
\hline \multicolumn{3}{|c|}{ Type of Sustainability Engagement } \\
\hline \multirow[t]{2}{*}{ Internal social sustainability } & Company C & $\begin{array}{l}\text { "it's our employees, colleagues, and the working conditions, where we are } \\
\text { following the law. As a high-quality company, we take care of our } \\
\text { employees, but we are a small company of } 35 \text { people and are more or less } \\
\text { like a family, so we are very good at internal social issues" }\end{array}$ \\
\hline & Company B & $\begin{array}{l}\text { "we work a lot with things like reducing stress and things like that } \\
\text { internally ... our main resource is our employees, so we are trying to make } \\
\text { sure that they do not overwork and so on-that is a priority for us" }\end{array}$ \\
\hline $\begin{array}{l}\text { External social } \\
\text { sustainability-local level }\end{array}$ & Company F & $\begin{array}{l}\text { "We are also helping a lot of local athletic clubs, for example, and have a } \\
\text { strategy around that. And I think that is also very important-I mean we } \\
\text { do not sponsor very big football clubs, but we sponsor smaller ones and } \\
\text { that's our idea of contributing" }\end{array}$ \\
\hline \multirow{3}{*}{$\begin{array}{l}\text { External social } \\
\text { sustainability—global level }\end{array}$} & Company C & $\begin{array}{l}\text { "then it comes to the suppliers and social issues-they also have to sign a } \\
\text { code of conduct, if you are in Europe you only need to sign it ... at the } \\
\text { beginning of the working relationship. However, if you are located outside } \\
\text { Europe, you need to sign it every year to secure that you are not using child } \\
\text { labor, not giving unfair wages or bad working conditions" }\end{array}$ \\
\hline & Company E & $\begin{array}{l}\text { "In China, most of the workers in the sewing companies ... live at the } \\
\text { factory but the children still live back home with their grandparents, so the } \\
\text { families ... meet once a year, and that's during the Chinese New Year. } \\
\text { That's terrible. So, what we did was when ... the children were out of } \\
\text { school, they could go to the factory, and we have a school for them there. } \\
\text { And then they could meet the parents in the evenings and have a nice time" }\end{array}$ \\
\hline & Company I & $\begin{array}{l}\text { "All our fabrics and suppliers, all our production plants are in Europe, and } \\
\text { we still have a demand when it comes to sustainability ... , as they are very } \\
\text { definite and well-connected. So all our suppliers and product producers' } \\
\text { needs to meet the requirements" }\end{array}$ \\
\hline \multirow{2}{*}{$\begin{array}{l}\text { Internal environmental } \\
\text { sustainability }\end{array}$} & Company D & $\begin{array}{l}\text { "The management has developed a strategy, "zero vision"- - we want zero } \\
\text { emissions to air, zero impact on the working environment and zero } \\
\text { pollution of water and soil- which is what we work for" }\end{array}$ \\
\hline & Company G & $\begin{array}{l}\text { "the production is run by green energy, so we are saying that the } \\
\text { production is climate-neutral, so there aren't any emissions from the energy } \\
\text { production" }\end{array}$ \\
\hline \multirow{3}{*}{$\begin{array}{l}\text { External environmental } \\
\text { sustainability }\end{array}$} & Company I & $\begin{array}{l}\text { "We work with their local legal parts to fulfill sustainability and } \\
\text { environmental issues. Also, when it comes to the fabric suppliers, we are } \\
\text { pushing them to manufacture and develop new fabrics, which are more } \\
\text { environmentally friendly than the ones on the markets right now" }\end{array}$ \\
\hline & Company $\mathrm{H}$ & $\begin{array}{l}\text { "biodiversity is also an important part because urbanization puts a lot of } \\
\text { pressure on biodiversity. So, we try to work very broadly on both the } \\
\text { positive and the negative side" }\end{array}$ \\
\hline & Company E & $\begin{array}{l}\text { "Its different sustainability, it's very difficult because in the US, or China } \\
\text { you have to have a plastic bag around everything" }\end{array}$ \\
\hline
\end{tabular}


Internal social sustainability revolves around the impact the company has on its workforce [48]. In this context, the participating SMEs' perception was that this should adhere to following the Swedish legislation for employment. All participants acknowledged the difficulty of addressing these issues beyond the law, which probably can be explained by the vagueness and poor conceptualization of the construct, as pointed out by Boström [49].

As for the company's external social sustainability practices, Longoni, Golini, and Cagliano [48] argue that these can directly affect the surrounding community. The participants' external social practices have shown to concur with this definition, but extend to include two different directions, (a) contributions to a local level (i.e., their direct community), and (b) contributions on a global level (i.e., concerns over suppliers' social sustainability).

Contributions for the local level included sponsoring local organizations and collaborations with local universities and schools, as company F stated (see Table 2). Furthermore, companies C, E, and H are other examples of how this type of engagement is perceived as their duty to the local community. Therefore, it can be argued that they are doing so not for financial gains, but due to personal and societal norms of conducting business, as suggested by Jansson, Nordlund, and Westin [50]. The global level (i.e., concerns over suppliers' social sustainability) emphasizes companies' demands on their suppliers for addressing social sustainability concerns, such as child labor and fair wages [51]. Most of the companies working on a global level with these issues, namely C, D, and E, are partly doing so because their supply chains include non-EU suppliers and sub-suppliers.

When it comes to the environmental pillar, one can discern between internal environmental performance (EP) [52] and external EP [53]. The internal was perceived to include the companies' considerations about, e.g., their employees' commute, whether their productions are run according to ISO 14001, and rational resource usage such as electricity, as companies D and G clarified. As for the external, these were perceived to revolve around greening their supply chains. The participants, who were engaged in external EP, highlighted these, as they argued firms can no longer ignore it. For instance, companies I and $\mathrm{H}$ have given us more in-depth reasoning of why this is the case, further company $\mathrm{H}$ presented us with the struggles of working with the different markets, especially the non-EU ones. Therefore, it can be assumed that companies could be restrained in their sustainability efforts if working with non-EU markets, which might require different strategies for addressing these issues. All companies and the extent of their sustainability practices are presented in Figure 3.

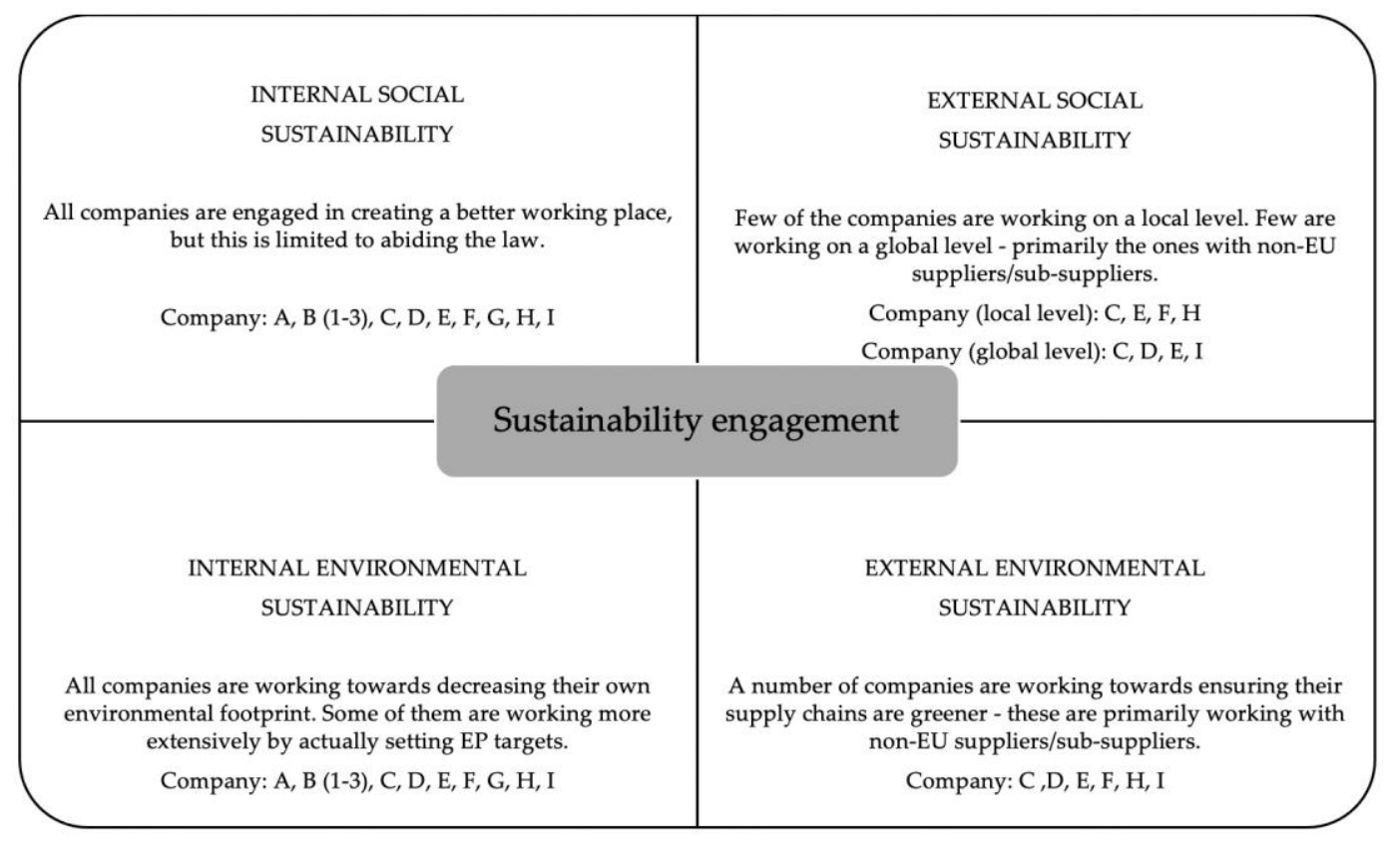

Figure 3. Type of sustainability engagement in the participating firms. 


\subsection{Drivers for Sustainable Development}

First research question: 'What are the external and internal factors and for the maintenance of sustainability practices in Swedish SMEs?'

\subsubsection{External Factors}

\section{Government}

The government has been argued to have a strong influence on adopting sustainability practices in the Scandinavian region [20]. However, it was perceived as having a rather weak influence on the maintenance component. This seemed to be the case, even if companies were working with the public sector, which in Sweden is governmentally owned. For instance, companies $\mathrm{F}$ and $\mathrm{H}$ work with tenders, but they argued that the government is rather focused on price than sustainability. The rest of the companies did not mention the government as a factor at all. However, all participants acknowledged that they are abiding by the law (e.g., company A and D, see Table 3), in terms of internal social sustainability and internal environmental sustainability.

Table 3. Direct quotes for 'government' as a factor.

\begin{tabular}{cc}
\hline & Company A $\begin{array}{l}\text { "Our operations are conducted in a way that the environment is preserved } \\
\text { but that's not our main focus. Our main focus is on the REACH legislation, } \\
\text { which covers what kind of substances you're allowed to have in the products" }\end{array}$ \\
\cline { 2 - 3 } Government & $\begin{array}{l}\text { "the company has been working with environmental legislation. In the past, } \\
\text { we wanted to fulfill what the law said but maybe not more than so" }\end{array}$ \\
\hline
\end{tabular}

\section{Networks and Alliances}

Networks and strategic alliances have a strong link for firms engaging in sustainability practices [34]. These are argued to be useful when building cooperative relationships between its participants for solving complex ecological problems [22], which has been the case for company I (see Table 4). However, this was not perceived as a factor in maintaining the practice. This also extends to the majority of the participants, as these are also a part of regional-level networks for sustainable development. Even though some of them were influenced by their respective sustainability networks (e.g., company C and F, see Table 4), the influence was rather in the way that they got inspiration from these.

Table 4. Direct quotes for 'network' as a factor.

\begin{tabular}{cl}
\hline Company I & $\begin{array}{l}\text { "We are also collaborating with a few of the other brands in this area } \\
\text { [sustainability] because we feel that we do so without having too } \\
\text { much competition" }\end{array}$ \\
\hline "We are a small company and we don't have a sustainability department, \\
"Company C $\begin{array}{l}\text { so it's just a small piece of a lot of different things that we do here, so for us, } \\
\text { it's important to be a part of a network, as the network can raise a lot of } \\
\text { question and inspire with suggestions for how things can be done" }\end{array}$ \\
$\begin{array}{l}\text { "We try to be active in that part, as I think that it is important that our staff } \\
\text { also get new ideas, so we can keep up and continue to develop our practice. } \\
\text { So I think mostly that is why we are a part of this network." }\end{array}$ \\
\hline
\end{tabular}

Therefore, the influence of such networks could have had a greater function for adopting sustainability practice, as suggested by Revell et al. [22], as it represents an additional resource, which can rarely be found within SMEs. However, these are not a vital driver for the maintenance component for their sustainability practices. 


\section{Competitors}

The competition encourages firms to engage in sustainability practices by mimicking competitors [54], where a positive link has been found between competition and environmentally sustainable performance [23]. However, when it concerns the maintenance aspect, the competition was perceived as a strong driver only in a few cases.

Table 5 shows some examples of how the competition is perceived by the participating SMEs. Company $B$ is an example of how different practices can be observed even within different divisions in a company, where B1 has to keep up with competition all the time, due to their sustainable business consulting practice. In contrast, divisions B2 and B3 are not driven by competition, due to the essence of their offering. In another case, namely company $\mathrm{G}$, the competition was rather perceived as an inspiration to further develop their own sustainability practice. Others (e.g., company E) did not consider it a strong driver, but at the same time, it gave them a competitive edge over others (see discussion under 'competitive advantage and strategic intent'). This in turn can perhaps force their competitors to adapt to their practice in the future.

Table 5. Direct quotes for 'competitors' as a factor.

\begin{tabular}{|c|c|c|}
\hline \multirow{4}{*}{ Competitors } & Company B, division B1 & $\begin{array}{l}\text { "it is our brand since we work with sustainable transport. } \\
\text { We can see that other consultancies have also started } \\
\text { working with sustainability, but we have worked with it } \\
\text { for so long now that it's easier to attract other interesting } \\
\text { customers who have decided to do something and not } \\
\text { only talk about sustainability" }\end{array}$ \\
\hline & Company B, division B2, and B3 & $\begin{array}{l}\text { "We want to include more sustainability into their } \\
\text { practice, but the kind of projects they have, don't always } \\
\text { integrate sustainability, so it is not really up to them to } \\
\text { lift these issues in the projects" }\end{array}$ \\
\hline & Company G & $\begin{array}{l}\text { "our competitors or other producers are very well } \\
\text { equipped for a sustainable future. And we as a small } \\
\text { company need to work both harder and faster to be at } \\
\text { the same level" }\end{array}$ \\
\hline & Company E & $\begin{array}{l}\text { "Maybe we don't earn so much money in China right } \\
\text { now, but in } 10 \text { years maybe it's our biggest market. } \\
\text { Then we still have our competitors, but we have a good } \\
\text { brand-so we have to trust our brand" }\end{array}$ \\
\hline
\end{tabular}

The participants, in their majority, are working internationally, therefore it is interesting to note that competition does not play a major role in maintaining their sustainability practices. However, in some cases, if a firm has started to expand its efforts, competitors' practices can serve as a useful tool. This can be partly explained by the fact that Sweden is among the first when it comes to sustainability practices on a global level $[13,20]$. At the same time, it can be considered that the lack of pressure, from competitors, originate from their know-how given the lengthy history of sustainable behavior in their domestic market.

\section{Suppliers}

It has been argued that suppliers could put pressure on SMEs for adopting sustainable practices, especially if these are a part of a global supply chain or have internationalized their operations [23,24]. That has been the prevailing tendency within the participants, for both internal and external sustainable engagement, as most of their supply chains are globalized. It seems that greening the supply chains is an important aspect of their sustainability practice, and it has been described as a strong driver for maintaining their practice (e.g., company A). Table 6 presents some perceptions of suppliers as a factor for maintaining sustainability practice. 
Table 6. Direct quotes for 'suppliers' as a factor.

\begin{tabular}{|c|c|c|}
\hline \multirow{4}{*}{ Suppliers } & Company A & $\begin{array}{l}\text { "you would have to go through some kind of supplier evaluation process } \\
\text { especially when working abroad", but then again "Supplier will not ask if you } \\
\text { are planning to take e.g., ISO } 14001 \text { in the next year or two, I mean they should be } \\
\text { asking but they don't" }\end{array}$ \\
\hline & Company C & $\begin{array}{l}\text { "For the suppliers in the Far East, we've had a long relationship with them, } \\
\text { and they have been our suppliers for many years--we are not looking for the } \\
\text { best price, we also want to know the suppliers" }\end{array}$ \\
\hline & Company D & $\begin{array}{l}\text { "To our suppliers that we buy our products from, our raw materials and } \\
\text { packaging and everything else, we also require them to meet our 'code of } \\
\text { conduct'. For us to be able to offer safe chemicals, we cannot buy raw materials } \\
\text {... that are not manufactured correctly, or where the employees ... do not have } \\
\text { access to protective equipment for example. We need good suppliers who can } \\
\text { give us good products" }\end{array}$ \\
\hline & Company E & $\begin{array}{l}\text { "There's a lot of difference in Europe, and especially Sweden is a little bit ahead. } \\
\text { That's a little bit difficult because I want to get rid of all plastic bags, but then we } \\
\text { can't sell them in Japan, so it's different for different markets" }\end{array}$ \\
\hline
\end{tabular}

The majority of companies (e.g., companies C and D) are also working towards greening their supply chains, by evaluating the sustainability practices of their suppliers and sub-suppliers. Contrary to this, company $\mathrm{E}$ has expressed their difficulties in maintaining and further developing their sustainability practice, when it concerns their non-EU markets. Companies $\mathrm{G}$ and $\mathrm{B}$ are the exceptions to this tendency, since the former has its production in Sweden and its suppliers within Europe, and the latter does not provide a tangible offering, which is their reasoning behind not engaging in greening their supply chains.

Therefore, it can be assumed that suppliers are a strong driver for firms when it comes to maintaining one's sustainable practice. However, the magnitude may be reduced, if the production is located domestically. Moreover, suppliers' influence and greening the supply chain seems to be highly dependent on whether or not a firm works with suppliers from non-EU countries.

\section{Customers}

Scholars have long argued that customers can increase SMEs' sustainability development through, for example, higher demand for green offerings [23,25]. This can be further reaffirmed, as the majority of the companies have positively identified customers as a strong driver for the maintenance of their sustainability practices (e.g., company D). However, some variations can be noticed depending on the type of customer (i.e., B2B and public), Table 7 shows examples of the SMEs perception.

When it comes to B2B customers, the findings show some contradictions. For example, company A and divisions B2 and B3 stated that sustainability is not the concern of their customers, hence they are in no way driven by that demand. The reason for this can be explained by the essence of their business, thus for company $\mathrm{A}$, it is the industry and its lower requirements for sustainable development. On the other hand, in divisions B2 and B3, it can be argued that since their offerings are intangible, and their customers dictate the price of the projects, sustainability may be left on the sidelines. In contrast, division B1, companies C and G have elaborated on the fact that their customers have started to prioritize sustainability, and hence are a strong driver for maintenance.

On the other hand, when speaking about public procurement, companies $\mathrm{F}$ and $\mathrm{H}$ argued that it is high on the agenda on paper, but in reality, follow-up is missing and the focus is still largely set on price. However, the informant from company I believes that even though that is the case, companies need to prioritize sustainability, to win the tenders of tomorrow.

Overall, customers appear to be a strong driver for the maintenance of sustainability practices, while their influence varies depending on them being B2B or public. If companies work primarily with B2B customers', sustainability appears to be high on the agenda, whereas if the public sector 
is addressed, a high degree of sustainability may be exchanged for a lower cost. However, in both cases, it can be argued that certain industries/sectors are possibly more concerned over the sustainable offering, as this might include higher benefits, such as the durability of the products.

Table 7. Direct quotes for 'customers' as a factor.

\begin{tabular}{|c|c|c|}
\hline \multirow{8}{*}{ Customers } & Company D & $\begin{array}{l}\text { "customers have a big impact ... they are becoming more } \\
\text { and more aware of the environment and that they should } \\
\text { buy as environmental and sustainable products as possible } \\
\ldots \text { our customers ask if we can offer something that is more } \\
\text { environmentally friendly or that may be eco-labeled } \\
\text { or similar" }\end{array}$ \\
\hline & Company A & $\begin{array}{l}\text { "Very few of our customers, maybe none of them are } \\
\text { concerned over CSR [sustainability] or environmental issues, } \\
\text { so we don't work in an environment where we are pushed to } \\
\text { be better at it from e.g., competition" }\end{array}$ \\
\hline & Company $\mathrm{B}$, division $\mathrm{B} 2$, and $\mathrm{B} 3$ & $\begin{array}{l}\text { "We want to include more sustainability in our practice, } \\
\text { but the kind of projects we get don't always integrate } \\
\text { sustainability, so it is not really up to us to lift these issues in } \\
\text { the projects" }\end{array}$ \\
\hline & Company C & $\begin{array}{l}\text { "back in } 2013 \text { it also became a demand from our biggest } \\
\text { customers and all of the big retailers in the market who resell } \\
\text { our products. One day they started asking questions if we } \\
\text { have this and that system and then we realized that it was } \\
\text { something we needed to do" }\end{array}$ \\
\hline & Company G & $\begin{array}{l}\text { "at the moment we are reconsidering the whole social issues } \\
\text { because we realize that we need to show this to our } \\
\text { customers, as they are interested to see how the company is } \\
\text { working with social issues" }\end{array}$ \\
\hline & Company F & $\begin{array}{l}\text { "It has been on very few occasions, that we have been } \\
\text { followed up on these, which we think is a bad thing, as we } \\
\text { are delivering a very good product according to these issues, } \\
\text { so actually we would like them to follow up on things- } \\
\text { but maybe they will in the future" }\end{array}$ \\
\hline & Company $\mathrm{H}$ & $\begin{array}{l}\text { "when it comes to public procurement, there is a big } \\
\text { challenge when it comes to sustainability because the whole } \\
\text { public procurement is focusing on price. So the lowest } \\
\text { bidder wins the task, which means that it's really hard to } \\
\text { push issues like innovation, quality, and sustainability } \\
\text { because you risk disqualifying yourself due to the cost" }\end{array}$ \\
\hline & Company I & $\begin{array}{l}\text { "If you think about it in that way, then you have to only } \\
\text { focus on winning the tender for tomorrow. But the } \\
\text { requirements will be more and more demanding. So, if you } \\
\text { don't have a focus on sustainability questions then there is } \\
\text { no way of winning tenders at the end of the day anyway" }\end{array}$ \\
\hline
\end{tabular}

Community Surroundings

Public demand for sustainability practices is among the driving forces [9]. However, the participating companies' interpretation of the word was restricted to include their local communities (see Table 8). On one hand, the participants (e.g., company C and F) are very involved in their communities, which can be explained by their size, thus the smaller the community, the higher the company's involvement. However, these examples do not attest to communities being a strong driver for maintenance of sustainability practices, but rather that this is the by-product of stronger drivers. It was only company $\mathrm{A}$, that mentioned this as a strong driver for developing and maintaining sustainability practices. 
Table 8. Direct quotes for 'community surrounding' as a factor.

\begin{tabular}{|c|c|c|}
\hline \multirow{4}{*}{ Community Surrounding } & Company C & $\begin{array}{l}\text { "Externally in society, our work is very active. We are } \\
\text { located in a small city ... , and our company is very active } \\
\text { in our home city-so we invite schools and different } \\
\text { associations to come and visit us and we try to be active in } \\
\text { our community" }\end{array}$ \\
\hline & Company F & $\begin{array}{l}\text { "our business is located in a small village, where there are } \\
\text { not that many people ... we are also helping a lot of local } \\
\text { athletic clubs" }\end{array}$ \\
\hline & Company A & $\begin{array}{l}\text { "I think that it's a legal demand from society as such, } \\
\text { you need to have it and pay attention to how you use raw } \\
\text { materials, how you source your waste and so on" }\end{array}$ \\
\hline & Company I & $\begin{array}{l}\text { "Now it's so important saying you cannot be in this } \\
\text { business without having it ... seven years ago we } \\
\text { wouldn't even consider having one full-time employee } \\
\text { working with that ... So, it's a high focus area and } \\
\text { probably still will be for some years to come" }\end{array}$ \\
\hline
\end{tabular}

Therefore, it is logical to assume that, if the public demand grows at a higher rate, then this driver may increase its strength, especially for the maintenance of sustainability practices. An increase in the public demand, for greener offerings, has been reported from some of the companies. This has led them to believe that companies can no longer afford not to have it, as the informant from company I stated.

\subsubsection{Internal Factors}

\section{Employees}

According to Zhang et al. [27] employees have a high impact when it comes to SMEs' adoption of environmental practices, and the successful implementation of these [26]. All of the companies acknowledged that their employees are an important factor for them to provide and maintain their sustainable work. Partly, because they want to offer a safe and good working environment, but also as they want to be considered an attractive workplace. However, the perception of how employees affect their work with sustainability differ.

For example, company $\mathrm{C}$ is addressing this importance by letting their employees be aware of their core values. This is also something that company $\mathrm{G}$ puts attention to, but differently (see Table 9). Therefore, companies are taking into consideration the employees' perspective, but it can be hard to please everyone when choosing the sustainability direction of a firm. Despite that, company D underlined that employees should not be afraid to raise their opinion of things that are not working properly and can be changed. Hence, employees' influence is not related to setting the direction of sustainable development, or the extent of it. However, it can be posited that these companies are cherishing their employees' values, and in turn, they are becoming a stronger influence on the maintenance component.

At the same time, companies B and I highlighted that their sustainability work was attracting new candidates. Therefore, one can reason that the organizations can additionally benefit from their sustainability work by attracting candidates with interest and knowledge in the area, which can help them to develop further. No matter the company's specific perception of the driver, it is considered as a driving force for maintaining, especially for the participating SMEs and their limited human resources. 
Table 9. Direct quotes for 'employees' as a factor.

\begin{tabular}{|c|c|c|}
\hline \multirow{6}{*}{ Employees } & Company A & $\begin{array}{l}\text { "... it's also from an employees' point of view-we want to be an attractive } \\
\text { company as we are still recruiting people ... And we need to have a policy } \\
\text { [sustainability related] that is attractive in the eyes of employees, as you should } \\
\text { be proud of the company you work in" }\end{array}$ \\
\hline & Company C & $\begin{array}{l}\text { "Since we are telling our employees that they are working in a high-quality } \\
\text { company, our company needs to work and behave accordingly" }\end{array}$ \\
\hline & Company G & $\begin{array}{l}\text { "Everybody has this chance to influence it ... but it comes with so many } \\
\text { different perspectives. So, I think for a company it's very important to put } \\
\text { down what sustainability means for our company" }\end{array}$ \\
\hline & Company D & $\begin{array}{l}\text { "Employees shouldn't be afraid to bring up things that they don't think are } \\
\text { working so that we can do better" }\end{array}$ \\
\hline & Company B & $\begin{array}{l}\text { "We can see that it's important for our employees because many people have } \\
\text { chosen to work with us because they have passion for sustainability, and it } \\
\text { gives them satisfaction to work with those sort of projects" }\end{array}$ \\
\hline & Company I & $\begin{array}{l}\text { "We have been quite attractive as an employer due to our focus on } \\
\text { sustainability. So, we have people contacting us and sending in CVs and things } \\
\text { like that, even if we don't have open positions" }\end{array}$ \\
\hline
\end{tabular}

Organizational Culture

According to Cambra-Fierro and Ruiz-Benítez [29] and Uhlaner et al. [30], organizational culture plays an important role in SMEs when it comes to formulating sustainability practices. The majority of the participating companies acknowledged that this driver has a strong influence also on the maintenance component, no matter if Type 1 (i.e., family-owned) or Type 2 (i.e., manager and board of directors operated).

Table 10 shows examples, where company D specifically recalled this as the biggest internal driver when the entire management of the company was replaced. Therefore, in this particular case, it is clear that it is the personality of the management that drives higher levels of engagement, even though the company is a Type 2 . Another Type 2 company is $\mathrm{H}$, which portrayed the culture as the foundation of their sustainability progress. Furthermore, the rest of the CEOs' of Type 1 companies (C, F, and I) expressed their thoughts when it came to enforcing the sustainability focus.

In contrast, it can be argued that company E's culture does not influence their current level of sustainability engagement, even though they are a Type 1 enterprise. A reason for that could be that they are in the process of improving. However, the quality manager hopes that consumers will start to ask even more questions about sustainability which will give the other departments an eye-opener of its importance.

It can be ascertained that no matter the type ( 1 or 2$)$, sustainability will be high on the agenda if the current management prioritizes it. Therefore, the maintenance component, within this factor, is driven by the owners' personality and interest, as argued in the literature for the adoption of sustainable practices [31,32]. Thus, if a manager's personal characteristics made him or her adopt sustainability practices, this will also drive him or her to maintain these. This can be further supported by the fact that companies A (Type 2), E, and G (Type 1) did not consider their organizational culture to be a driving force behind their development of sustainability, it is there but it is not the defining factor. 
Table 10. Direct quotes for 'organizational culture' as a factor.

\begin{tabular}{|c|c|c|}
\hline \multirow{6}{*}{ Organizational culture } & Company D & $\begin{array}{l}\text { "When it comes to the internal, I would say that we have an } \\
\text { extremely big advantage in this company, the management and the } \\
\text { owners think this is very important" }\end{array}$ \\
\hline & Company $\mathrm{H}$ & $\begin{array}{l}\text { "it's very important if we want to create social sustainability and } \\
\text { value for the society, we have to put the } 48 \text { employees in the center } \\
\text { of the development ... it's the next generation that we also have to } \\
\text { focus on ... it's not about the market, it's not about legislation- } \\
\text { it's the people that we have" }\end{array}$ \\
\hline & Company F & $\begin{array}{l}\text { "The first and most important factor is that I am building a company } \\
\text { that must work sustainably ... So, from the very beginning, it was } \\
\text { much more internal factors, since I wanted to build a good } \\
\text { foundation for the company" }\end{array}$ \\
\hline & Company $\mathrm{C}$ & $\begin{array}{l}\text { "We consider ourselves as a high-quality company and not only } \\
\text { with the products we make but also in general ... high-quality } \\
\text { products and a high-quality company should be linked to social } \\
\text { responsibility" }\end{array}$ \\
\hline & Company I & $\begin{array}{l}\text { "it's never an option to compromise on sustainability for us ... } \\
\text { it's not an option to not have it so high on the agenda, since we } \\
\text { know our industry has a negative impact" }\end{array}$ \\
\hline & Company E & $\begin{array}{l}\text { "My target now for the last year has been to get the owners to } \\
\text { prioritize sustainability ... Last summer I was visiting them all, } \\
\text { the owner and the children, and had some sustainability talks with } \\
\text { them. It was so good, and I think we will get the resources and it } \\
\text { will be on top of the management that sustainability is important" }\end{array}$ \\
\hline
\end{tabular}

Brand Image and Reputation

According to Agan et al. [33], companies are engaging in sustainable practices, especially EP, as a way to improve or green their image and brand name. This factor has been described as a particularly strong one [29,31], as it can influence all important stakeholders.

For instance, company B (1-3) is working with transforming a whole sector to a more sustainable one, so all of their activities revolve around improving sustainability practices-both for them and for their customers. This also holds for company $G$, which considers this to be the biggest internal driver. Furthermore, company D explains that they are very proud of their brand, which is strongly associated with sustainability and further encouraging them to maintain their practice. Contrary to these, three other participants (A, F, and E) did not see this as a strong driver for maintenance (see Table 11).

Table 11. Direct quotes for 'brand image and reputation' as a factor.

\begin{tabular}{|c|c|c|}
\hline \multirow{5}{*}{ Brand image and reputation } & Company G & $\begin{array}{l}\text { "And even more brand image and improved reputation. I think that's } \\
\text { the main force that we see driving our sustainability work" }\end{array}$ \\
\hline & Company D & $\begin{array}{l}\text { "it's easier for us to market ourselves as a desirable company when we } \\
\text { have this environment and sustainability work" }\end{array}$ \\
\hline & Company A & "In our case, it is less about looking good and more about the economy" \\
\hline & Company F & $\begin{array}{l}\text { "We don't communicate it [sustainability] that much as we address it, } \\
\text { but it is not one of the most important aspects for us" }\end{array}$ \\
\hline & Company E & $\begin{array}{l}\text { "It's difficult, we present our company as sustainable in what we do and } \\
\text { everything, but at the same time we don't want it to be the main focus" }\end{array}$ \\
\hline
\end{tabular}

The issue of whether this driver has excessive influence over the maintenance component for sustainability can be found in the specific company's perception of why they engaged in it in the first place. Or in other words, for some companies achieving a better brand image and reputation 
came as a by-product of their progress of sustainability, which was driven by other factors. However, others engaged in such practices with the preexisting expectations that they wanted to achieve a better reputation and image. Thus, in some cases, the participants were maintaining their practice as a way to keep up with their green reputation, which has resulted in it being a strong driver.

Stakeholders' perception of brand image can also be connected to a firm's communication efforts. Therefore, during the online research before contacting the firms, it was interesting to notice that the majority of them did not emphasize their sustainability actions on firms' websites. Partly this might be attributed to them not wanting to be perceived as greenwashing their stakeholders, while others did not consider their websites/social media accounts to be appropriate for this, due to their customer segments being primarily $\mathrm{B} 2 \mathrm{~B}$ and public.

Competitive Advantage and Strategic Intent

Achieving competitive advantage has been described as a strong motivator for the adoption of sustainability practice [55], or reduction of costs as a strategic intent [34]. Not surprisingly all participants acknowledged that there has been a strategic intent for adopting sustainable practices [34], which has also transformed into a strong driver for maintenance. This driver can be associated with cost-saving intentions even for maintenance, but this perception might not have the strongest influence. It appears that the strategic intent and deliberation have a strong influence on maintenance. This is no matter if it is about (a) being more competitive on the domestic and global market (e.g., A, B (1-3), D, F, and $\mathrm{H}),(\mathrm{b})$ the strategic intent for improving stakeholders' perception, and the general direction for development (e.g., C) or (c) a mixture of the two (e.g., E, G and I).

Drawing on all of the presented examples in Table 12, one can make the distinction that companies mainly maintain their sustainability practices, due to their perceived competitiveness in their market, and not because of strategic intent. However, the general direction of where the company is heading (strategic intent) has been described as a strong driver for the SMEs to further develop their sustainability. Both aspects of the driver can be further connected to the perception of the majority of the participating SMEs, and their intent to ensure the long-term survival of their companies.

Table 12. Direct quotes for 'competitive advantage and strategic intent' as a factor.

\begin{tabular}{|c|c|c|}
\hline \multirow[b]{4}{*}{ Competitive advantage and strategic intent } & Company A & $\begin{array}{l}\text { "As we started working with different processes and we wanted } \\
\text { to look more attractive in the international marketplace ... } \\
\text { we hired an external consultant who had a more modern } \\
\text { approach to quality and environmental approach" }\end{array}$ \\
\hline & Company D & $\begin{array}{l}\text { "becoming more competitive, we can stand out in the industry if } \\
\text { we can offer more environmentally and sustainable products" }\end{array}$ \\
\hline & Company C & $\begin{array}{l}\text { "most of the products are made in Sweden and that is our } \\
\text { heritage, and that is also our strategy" }\end{array}$ \\
\hline & Company E & $\begin{array}{l}\text { "I think this is 'självklart' [obvious], we need to have it-both } \\
\text { internal and also for the future I think as the base for a company. } \\
\text { It's not like you shall beat your competitors on this-this is } \\
\text { something you need to have to exist in the future. I think we have } \\
\text { learned that" }\end{array}$ \\
\hline
\end{tabular}

Size of the Firm

According to Reyes-Rodríguez et al. [36] size plays a major role for SMEs when adopting sustainable practices, especially the environmental aspects of it, where the bigger the company the more likely they are to adopt [38]. However, none of the participating SMEs mentioned size as an important driver for the maintenance component. Their perception was more in the lines that they as a company, no matter their size, have a responsibility toward society and the environment. It can also be 
argued that SMEs do not perceive their size as a driver, possibly because they are not aware of the limitations it entails. Based on this, they reflected on the fact that their practice cannot be compared to a large company's, but they did find a way to contribute to the further development of the UN's SDGs. A reflective example here is company $\mathrm{C}$, which is presented in Table 13.

Table 13. Direct quotes for the 'size of the firm' as a factor.

\begin{tabular}{l} 
Company C $\begin{array}{l}\text { "We are a small company and we don't have a sustainability department, } \\
\text { so it's just a small piece of a lot of different things that we do here ... I think } \\
\text { it's easy for the bigger companies with a whole department working with } \\
\text { these questions, but for us, it's not like that at all" }\end{array}$ \\
$\begin{array}{l}\text { "We have suppliers in Turkey, Vietnam, and China ... We have close } \\
\text { cooperation, and we can trust them that they pay the salaries, that they } \\
\text { have fire safety, safety in the production, and everything. So, that's one of } \\
\text { the most important factors for us. It's a long relationship ... but we make } \\
\text { third-party audits from professional companies ... they check the } \\
\text { production and everything, and then we get a full report about everything } \\
\text {... and they always find something, e.g., they work too much, ... that they } \\
\text { don't use the protections in the production and so on. But it's good, } \\
\text { we have good control, and they know that we are coming every year, } \\
\text { so they don't dare to do anything" }\end{array}$ \\
\hline
\end{tabular}

After comparing the size of the participating firm against their type of sustainability engagement few things stand out. Firstly, the size (i.e., whether small or medium) is not directly dictating the extent of the firms' sustainability practice. For instance, company $\mathrm{C}$ and I are small firms, with limited human resources, but they are one of the few participants whose practices extend to all types of sustainability engagement (shown in Figure 3). This is further supported by the fact that companies D, E, F, and H, all of which are categorized as medium-sized, can also be found within these four quadrants of sustainable engagement. Furthermore, it can be argued that the type of sustainability engagement was rather provoked by the use of non-EU suppliers and sub-suppliers, especially for the social pillar. Companies C, D, E, and I have included external social sustainability, even though this requires more extensive resources and time.

Figure 4 summarizes the most influential external and internal factors for maintaining sustainability practices as identified in the study.

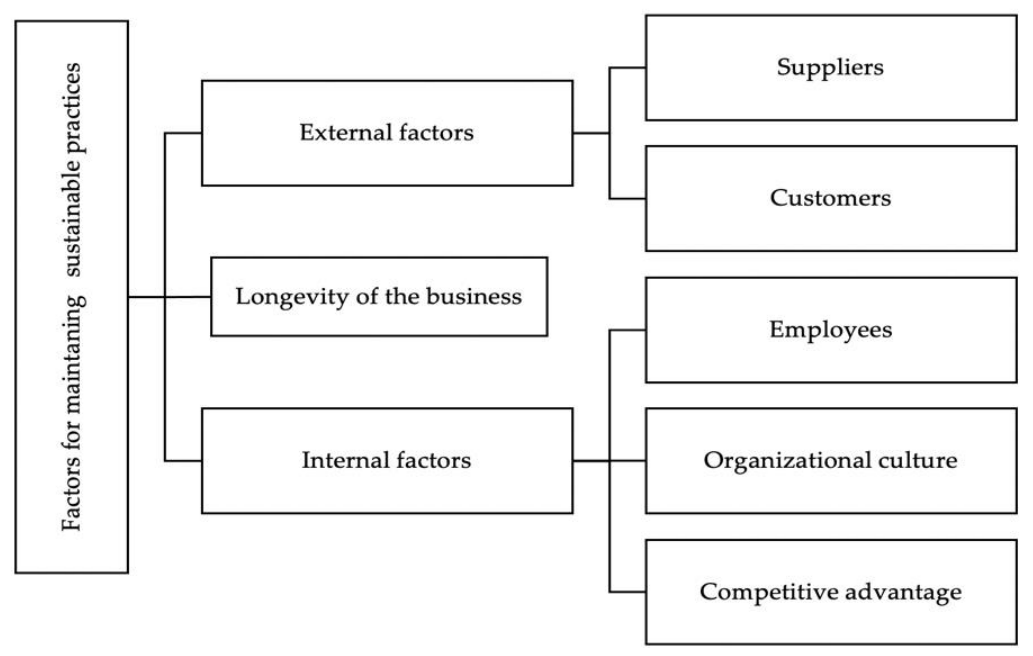

Figure 4. External and internal factors influencing the maintenance of sustainability practices. 


\subsection{Progress of Business Sustainability Practices}

The following focused on the second research question: 'How far have Swedish SMEs come in their sustainability practices?' The current positioning and progress of the participating SMEs have been synthesized in Figure 5, it is the outcome of interpretation and analysis presented in the previous sections.

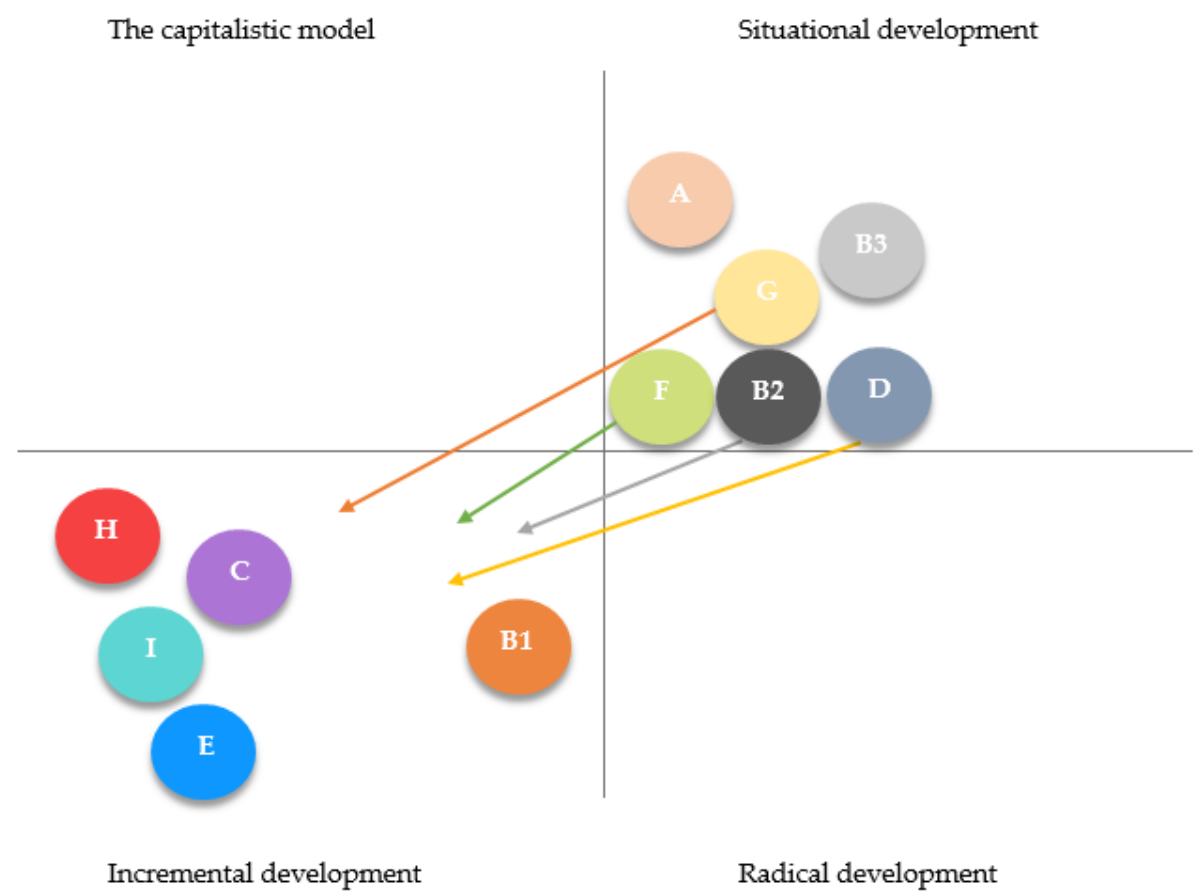

Figure 5. Current state and development of the firms' sustainable practices.

Reflecting upon the selected group of participants, the CEO of company A had an interesting remark to share "Most small and medium-sized companies, and especially if you are in a traditional business like we are, so it's not new economy then you will take the actions that you need, but it would never be a part of your DNA, as it will be if you are a start-up business when you want to make a statement and that's not where we are and this will not give us any more customers" (Interviewee 1). Since this was the first interview, we kept this in mind. However, our findings clearly showed that this is not the case. This is further strengthened by the fact that all participants, except company $\mathrm{B}$, have a traditional (i.e., pipeline) business model, or as the CEO called it, not a new economy.

\subsubsection{Company A}

Company A is placed in the quadrant of situational development mainly because of their restricted level of engagement, which includes both internal social and internal environmental. They are adopting some sustainability, but their key focus remains largely on economic prosperity. The CEO of the company stated that they are approaching it in a very pragmatic way, thus keeping the law but in addition to that, they will not work with processes, which do not make commercial sense. Compared to the other companies, A is the one with the least experience and does not consider themselves strong within the area. One reason for this could be that they are neither exposed to direct pressure from customers, nor the market itself.

\subsubsection{Company B}

As can be seen in Figure 4, the sustainable development within company B's divisions differs from each other. Therefore, these have been situated within different quadrants of the matrix. For example, division $\mathrm{B} 1$ has been placed in the incremental development, close to the radical development quadrant. 
The reason lies in the fact that the essence of the business (i.e., creating strategies for sustainable development) has eliminated the search for balance between the three pillars of the TBL. However, this type is also considered not truly sustainable, as even though the business has strong sustainability thinking, the focus remains on economic prosperity. Another important factor to be considered is that B1 is primarily working within Sweden and the Nordic countries, which has also accelerated their movement from quadrant two to three, due to the long history of sustainability in the regions [20].

In contrast, B2 and B3 have been placed in the situational development quadrant. B2 has been situated close to the incremental development, as they are dealing with sustainability more than B3, but not as extensively as B1. The sustainability coordinator explained that they consider their environmental footprint, but the priority is still cost-saving. It can be argued that B2 is borderline incremental, it still has not reached this quadrant, but is currently developing. On the other hand, B3 is placed nearby company A, and further away from B2, since their efforts are not as extensive as B2. This could be explained by the fact that it is their customers who dictate the extent of their external practice.

\subsubsection{Company C}

Company $\mathrm{C}$ is positioned in the incremental development quadrant further away from $\mathrm{B} 1$ since they are not as close to reaching the fourth one, but still, they are deliberately developing their sustainability practice. In contrast to company $\mathrm{A}$, company $\mathrm{C}$ faces higher demands from their biggest customers who resell their products, but also from the end consumers. This is one of the few companies engaging in all four types of sustainability engagement.

\subsubsection{Company D}

Company $\mathrm{D}$ is currently placed in the situational quadrant but is in very close proximity to the incremental development. The reason for this progress lies in the fact that the entire management was replaced, thus shifting the focus to sustainability. However, the company is still in its initial phases of development, where they are currently focusing on their strategy, called zero vision, which is to be implemented by 2030 .

\subsubsection{Company E}

Company $\mathrm{E}$ can be found in the incremental quadrant. The reason why they are not further is because of their restricted focus regarding the external sustainability practices, in comparison with H's markets, which are more globally spread. However, the differences in their markets might hinder their progress, since they are working also with non-EU markets, such as Japan where plastic bags are mandatory.

\subsubsection{Company F}

Company F can be considered as 'stuck in the middle', as they can be situated in the situational development quadrant, as well as the incremental development one. However, it was considered appropriate to place it within the former, but strongly moving towards the latter. The reason for this is that the company undoubtedly has a strong sustainability practice, but its strongest focus is financial viability. It has to be acknowledged, however, that this can be partly explained by the company's public customer segment. In their case, serving public customers means that there is a high degree of tenders. Therefore, by focusing more on sustainability the price can increase, which in turn will lead to losing the contract.

\subsubsection{Company G}

Company $\mathrm{G}$ is placed in the quadrant of situational development. Their position derives mainly due to their limited focus on internal and lack of external social sustainability efforts. This can be 
explained by the fact that the company has its production in Sweden and its supplier within the EU. Although, they are reconsidering due to issues of anti-bribery and corruption. However, they seem to be in the frontline regarding their internal EP and they are currently creating a strategic plan for developing their sustainability practice for the future, to increase the longevity of the business.

\subsubsection{Company $\mathrm{H}$}

As for company $\mathrm{H}$, it can be argued that they are in the incremental development quadrant, but have not come as far to the radical development, such as the other companies situated in this stage. $\mathrm{H}$ has a strong focus when it comes to both internal and external aspects of sustainability, however, in the end, it is the clients' demands that drive their final level of external sustainability efforts. At the same time, company $\mathrm{H}$ is perhaps the one that has the strongest internal sustainability practices, when it comes to both the social and environmental pillars since they set specific targets e.g., waste and printing.

\subsubsection{Company I}

Company I is placed within the incremental quadrant, close to companies $\mathrm{C}$ and $\mathrm{E}$, and further away from company $\mathrm{H}$. The reason for this is because company I is working with almost all types of sustainability engagement, except the local level of external social sustainability, which is the case for $\mathrm{C}$ and $\mathrm{E}$. Interestingly, this has been the only company that mentions that sustainability is no longer a choice. The CEO considered that the lack of choice coming from their industry (the textile) and its focus on being more circular. At the same time, the company is strong within its internal sustainability, even though they have completely outsourced their production, but they are focusing on being as self-sufficient as possible.

As Dyllick and Muff [14] argue, businesses need to completely shift their current way of thinking if they are to reach the Radical development stage, or as the authors call it 'Business Sustainability 3.0'. Furthermore, they suggest that within 'Business Sustainability 1.0 and 2.0', businesses are engaging for reward-based incentives, typically financial ones. Though, it became known that these incentives, especially for the studied maintenance component, could not be purely financial such as cost reduction. Thus, this also confirms the findings of Agan et al. [33] that intangible motivators, such as improved public perception, attracting new employees, and an extended pool of customers are vital also for the maintenance component.

Our findings suggest that reaching the fourth quadrant 'Radical development' (i.e., Business Sustainability 3.0) can prove challenging, especially for commercial businesses, as Dyllick and Muff [14] argue. It has been acknowledged that all participating SMEs have an inside-out approach, however, these are also progressing in their practices, and the majority of them will probably soon be situated in the 'Incremental development' quadrant (i.e., Business Sustainability 2.0).

Another interesting finding is that industry pressures seem to have started to change towards more sustainable ones. This could be the result of bigger industry players putting sustainability high on the agenda, from nice-to-have to must-have, or due to the increased maturity of the industries. Additionally, the SMEs' own perception of sustainability plays a major role, as the majority of the participating firms consider it as a long-term phenomenon, which is 'here to stay'. The majority of the SMEs did not have sustainability in their DNA. Hence, proving that firms can acquire the necessary knowledge and proceed toward a higher level in their sustainability thinking, even without it.

Nearly all of the participating companies are manufacturers of tangible offerings, which has positively reflected on the maintenance of their sustainability practice. Therefore, it can be assumed that if the offering is tangible, this increases the chance of it being a strong driver for the maintenance and further development of sustainability practices. Furthermore, since this investigation has considered size as a driver (being an SME), it has to be pointed out that the findings, in general, did not indicate that this is connected neither to their position in the matrix nor to the maintenance component. 


\section{Recommendations and Implications}

This study has practical implications for owners or managers of SMEs as well as policymakers.

\subsection{Sustainability Should Be a Long-Term Strategy}

If SMEs are to enjoy the full extent of their sustainability practices, e.g., more extensive customer portfolios or preserving their competitive advantage, these practices should be maintained for the long-term. In that relation, SME owners and managers might consider participating in networks and alliances of SMEs, exchanging ideas, and get inspiration about how to further develop their practices. In turn, policymakers might consider elaborating on the benefits that SMEs might experience, if maintaining their sustainability practices, through e.g., initiatives and campaigns.

\subsection{Sustainability Should Be Transparent}

To achieve this, SME owners should track their sustainability performance, which can be done via sustainability reporting. There are several ways for this to be done: (a) as a section within the annual report, (b) as a separate sustainability report, or (c) by using the SDGs as a template for reporting. Furthermore, policymakers need to emphasize the importance of it being transparent and guide businesses on the way to achieving this.

\subsection{Sustainability Efforts Should Be Properly Communicated Externally}

Social media can serve as a good resource marketing-wise, as it can help businesses to emphasize their sustainability efforts. It has to be remembered though, that when marketing their efforts businesses need to mirror their actual performance without exaggerating (greenwashing). To help businesses, policymakers can ensure that there are clear guidelines and a distinction between the two.

\subsection{Sustainability Should Be Considered as Contributing to the Longevity of the Business}

SME owners should consider putting up long-term goals and develop strategies for the future development of their sustainability practices. Industries and customers' demands are changing rapidly, meaning that if businesses are stuck in their old business models and unwilling to change, they might be lagging behind competitors. Businesses might consider adopting a holistic approach, where each company needs to find a balance between the three pillars. This would mean that a company can reflect upon which of the 17 SDGs they can contribute to, and direct their efforts there. Policymakers can appeal to the individual businessman by promoting sustainability as a tool for ensuring the longevity of the business, rather than implementing it as a good-to-have practice.

\subsection{The Social Aspect of Sustainability Is also Important}

It can be argued that the social pillar can be more difficult to operationalize than the environmental one, though businesses should not leave it aside. The internal aspect should extend beyond the SMEs' perception of 'following the law' and should rather focus on creating a sustainable work place.

\subsection{What to Do, If in the 'Situational Quadrant'?}

If placed in this quadrant, it means that a business is rather restricted in their practice, especially when it comes to the external aspects. Therefore, SMEs need to develop these, no matter if they serve a domestic or international marketplace since one needs to be prepared for rising challenges. Furthermore, SMEs need to improve the management aspect when it comes to TBL, thus becoming better at prioritizing sustainability if they would like to move on to the next quadrant.

\subsection{What to Do, If in the 'Incremental Quadrant'?}

If placed in this quadrant it means that a business has a good grasp of managing the TBL to a certain degree. However, if businesses in their future are to ever achieve 'True Sustainability' this will 
require solid foundations and a $360^{\circ}$ shift in the dominant business logic. Instead of focusing purely on sustainability within their operations, they can examine and consciously choose some of the UNs' SDGs within which they can drive change.

Maintaining and further developing sustainability practices will enable movement between the quadrants and will benefit SMEs both externally and internally. An action plan could be useful for showing how smaller firms can successfully progress from one quadrant to another until true sustainability is reached.

\section{Limitations and Future Research Agenda}

As with any research, the present study has limitations. We acknowledge that the sample size can be considered small. The main explanation for this was the extraordinary circumstance caused by COVID-19, which led to several rejections regarding study participation. The topic of this study should be relevant for SMEs operating in different sectors, and the findings obtained revealed certain trends that should lessen this limitation, yet the findings still need to be taken with caution. The cross-sectional design of the study can be considered as another limitation. Hence, a future research agenda can be for researchers to consider a longitudinal study, with a specific focus on the second research question. In that case, one could focus and track small firms transitioning from 'Situational development' to 'Incremental development'. Such a study would get a better insight into what is needed to move further within the matrix, which can give more in-depth guidelines on what efforts will be needed if small businesses are to reach the fourth quadrant 'Radical development'.

Furthermore, our focus was to examine SMEs and their sustainability practices, thus micro-sized companies were excluded. However, micro-sized companies and start-ups could potentially be further along in their sustainability thinking, if that is strongly embedded, or in the DNA of the business. This could represent another future research direction, the findings of which can be compared to our findings. Last but not least, it has to be mentioned that the findings of this paper have derived from investigating only Swedish SMEs. Given the fact that perhaps sustainability practices differ from country to country, the results might be applicable only in the context of Sweden or similar contexts, thus (statistical generalization) was not possible (and also not aimed for; given the study's exploratory nature). Nevertheless, it gives the possibility of replicating this study in other country contexts for testing the transferability of the study's findings.

\section{Conclusions}

In regards to the first research question, we found that two external factors were considered as strong motivators, namely suppliers and customers for the maintenance component. Furthermore, for the internal drivers, three were considered as the strongest, namely employees, organizational culture, and competitive advantage/strategic intent. This confirms that these two externals and three internal factors are the most influential ones which guide and direct the companies to maintain and develop their sustainability practices. While these five factors are regarded as strong motivators for maintenance, the majority of the participating SMEs emphasized the fact that they are building their businesses for future generations. Thus, it can be argued that it is the owners' perception of longevity that puts sustainability high on the agenda if the business is expected to meet the requirements of tomorrow.

As for the second research question, we found out that there were a few companies firmly situated in the 'Incremental development', and also a few which were moving towards that stage from the 'Situational development', by further developing their practices. However, none of the investigated SMEs have reached the 'Radical development' quadrant, or the True Sustainability 3.0. The current existence of truly sustainable businesses is doubtful, as this will require a $360^{\circ}$ change in the dominant business logic. It can be argued that the extent of their sustainability thinking, and progress has been strongly influenced by their respective industries. At the same time, their markets (i.e., whether $\mathrm{EU}$ or non-EU, domestic or international) and their customer segments (i.e., public, B2B, or B2C) 
were significantly influencing the type of sustainability engagement companies had. Furthermore, the sustainability focus has somewhat moved from an internal sustainability practice to external ones, where the latter is in focus. The typology proposed by Dyllick and Muff [14] has, to our knowledge, not been empirically tested yet, especially not within SMEs. Hence, by developing a practical framework we have expanded the theoretical knowledge, and have increased the possibility of empirically testing the types to track their current state and trace their progress through it. Although, we have to admit that it was challenging to place the companies within the matrix because there was no clear positioning technique for each quadrant. However, after extensive discussions, the participants were placed, and arguments were provided to strengthen their position. Additionally, we found it possible for a firm to be 'stuck in the middle' (i.e., symbolizing a positive movement), as in some cases it was difficult to appoint their place, as they could fit within two quadrants.

In summary, the present paper contributes to research on sustainability practices in SMEs in general. By providing insight into what SMEs are doing to maintain these practices the paper contributes to a deeper understanding of the topic. Additionally, the paper highlights the usefulness of Dyllick and Muff's typology for addressing different types of questions related to business sustainability.

Author Contributions: D.T. and E.B. have contributed equally and substantially to the work reported, which was based on their Master thesis. S.D. has acted as the supervisor of the original work and has contributed to writing, reviewing, and editing the present manuscript. All authors have read and agreed to the published version of the manuscript.

Funding: This research received no external funding.

Acknowledgments: We would like to extend our thanks to all participating companies, which took the time to speak with us, even during the extraordinary circumstances. Without their help and assistance, the outcome of the paper would not have been feasible.

Conflicts of Interest: The authors declare no conflict of interest.

\section{References}

1. Gupta, S.; Kumar, V. Sustainability as corporate culture of a brand for superior performance. J. World Bus. 2013, 48, 311-320. [CrossRef]

2. Johnson, M.P.; Schaltegger, S. Two decades of sustainability management tools for SMEs: How far have we come? J. Small Bus. Manag. 2016, 54, 481-505. [CrossRef]

3. López-Pérez, M.E.; Melero-Polo, I.; Vázquez-Carrasco, R.; Cambra-Fierro, J. Sustainability and business outcomes in the context of SMEs: Comparing family firms vs. nonfamily firms. Sustainability 2018, 10, 4080. [CrossRef]

4. OECD. Enhancing the Contributions of SMEs in a Global and Digitized Economy; OECD Publishing: Paris, France, 2017; Available online: https://www.oecd.org/industry/C-MIN-2017-8-EN.pdf (accessed on 8 February 2020).

5. Tillväxtverket. Basfakta om Företag. Available online: https:/tillvaxtverket.se/statistik/foretagande/basfaktaom-foretag.html (accessed on 2 March 2020).

6. Khattak, M.S. Does access to domestic finance and international finance contribute to sustainable development goals? Implications for policymakers. J. Public Aff. 2020, 20. [CrossRef]

7. European Commission. Long-Term Vision for a Sustainable Future. Available online: https:/ec.europa.eu/ environment/efe/news/long-term-vision-sustainable-future-2016-1220_en (accessed on 29 February 2020).

8. Cohen, B.; Winn, M. Market imperfections, opportunity and sustainable entrepreneurship. J. Bus. Ventur. 2007, 22, 29-49. [CrossRef]

9. Jansson, J.; Nilsson, J.; Modig, F.; Hed Vall, G. Commitment to sustainability in small and medium-sized enterprises: The influence of strategic orientations and management values. Bus. Strategy Environ. 2017, 26, 69-83. [CrossRef]

10. Horak, S.; Arya, B.; Ismail, K.M. Organizational sustainability determinants in different cultural settings: A conceptual framework. Bus. Strategy Environ. 2018, 27, 528-546. [CrossRef]

11. Jamali, D.; Zanhour, M.; Keshishian, T. Peculiar strengths and relational attributes of SMEs in the context of CSR. J. Bus. Ethics 2009, 87, 355-377. [CrossRef] 
12. Murillo, D.; Lozano, J.M. SMEs and CSR: An Approach to CSR in their Own Words. J. Bus. Ethics 2006, 67, 227-240. [CrossRef]

13. Sachs, J.; Schmidt-Traub, G.; Kroll, C.; Lafortune, G.; Fuller, G.; Woelm, F. The Sustainable Development Goals and COVID-19; Sustainable Development Report 2020; Cambridge University Press: Cambridge, UK, 2020; Available online: https://s3.amazonaws.com/sustainabledevelopment.report/2020/2020_sustainable_ development_report.pdf (accessed on 26 November 2020).

14. Dyllick, T.; Muff, K. Clarifying the meaning of sustainable business: Introducing a typology from business-as-usual to true business sustainability. Organ. Environ. 2016, 29, 156-174. [CrossRef]

15. Purvis, B.; Mao, Y.; Robinson, D. Three pillars of sustainability: In search of conceptual origins. Sustain. Sci. 2019, 14, 681-695. [CrossRef]

16. Jackson, A.; Boswell, K.; Davis, D. Sustainability and triple bottom line reporting-What is it all about? Int. J. Bus. Humanit. Technol. 2011, 1, 55-59.

17. Government Offices of Sweden. Sustainable Business- a Platform for Swedish Action. Available online: https://www.government.se/49b750/contentassets/539615aa3b334f3cbedb80a2b56a22cb/sustainablebusiness---a-platform-for-swedish-action (accessed on 20 March 2020).

18. Bossle, M.B.; de Barcellos, M.D.; Vieira, L.M.; Sauvée, L. The drivers for adoption of ecoinnovation. J. Clean. Prod. 2016, 113, 861-872. [CrossRef]

19. Yadav, N.; Gupta, K.; Rani, L.; Rawat, D. Drivers of sustainability practices and SMEs: A systematic literature review. Eur. J. Sustain. Dev. 2018, 7, 531-544. [CrossRef]

20. Strand, R.; Freeman, R.E.; Hockerts, K. Corporate social responsibility and sustainability in Scandinavia: An overview. J. Bus. Ethics 2015, 127, 1-15. [CrossRef]

21. United Nations. Sweden and the 2030 Agenda-Report to the UN High Level Political Forum 2017 on Sustainable Development. Available online: https://sustainabledevelopment.un.org/content/documents/ 16033Sweden.pdf (accessed on 13 May 2020).

22. Revell, A.; Stokes, D.; Chen, H. Small businesses and the environment: Turning over a new leaf? Bus. Strategy Environ. 2010, 19, 273-288. [CrossRef]

23. Lee, S.Y.; Klassen, R.D. Drivers and enablers that foster environmental management capabilities in small-and medium-sized suppliers in supply chains. Prod. Oper. Manag. 2008, 17, 573-586. [CrossRef]

24. Lee, S. Drivers for the participation of small and medium-sized suppliers in green supply chain initiatives. Supply Chain Manag. Int. J. 2008, 13, 185-198. [CrossRef]

25. Sáez-Martínez, F.J.; Díaz-García, C.; González-Moreno, Á. Factors promoting environmental responsibility in European SMEs: The effect on performance. Sustainability 2016, 8, 898. [CrossRef]

26. Venturelli, A.; Cosma, S.; Leopizzi, R. Stakeholder engagement: An evaluation of European banks. Corp. Soc. Responsib. Environ. Manag. 2018, 25, 690-703. [CrossRef]

27. Zhang, B.; Bi, J.; Liu, B. Drivers and barriers to engage enterprises in environmental management initiatives in Suzhou Industrial Park, China. Front. Environ. Sci. Eng. China 2009, 3, 210-220. [CrossRef]

28. Masurel, E. Why SMEs invest in environmental measures: Sustainability evidence from small and medium-sized printing firms. Bus. Strategy Environ. 2007, 16, 190-201. [CrossRef]

29. Cambra-Fierro, J.; Ruiz-Benítez, R. Sustainable business practices in Spain: A two-case study. Eur. Bus. Rev. 2011, 23, 401-412. [CrossRef]

30. Uhlaner, L.M.; Berent-Braun, M.M.; Jeurissen, R.J.M.; de Wit, G. Beyond size: Predicting engagement in environmental management practices of Dutch SMEs. J. Bus. Ethics 2012, 109, 411-429. [CrossRef]

31. Battisti, M.; Perry, M. Walking the talk? Environmental responsibility from the perspective of small-business owners. Corp. Soc. Responsib. Environ. Manag. 2011, 18, 172-185. [CrossRef]

32. Fassin, Y.; Van Rossem, A.; Buelens, M. Small-business owner-managers' perceptions of business ethics and CSR-related concepts. J. Bus. Ethics 2011, 98, 425-453. [CrossRef]

33. Agan, Y.; Acar, M.F.; Borodin, A. Drivers of environmental processes and their impact on performance: A study of Turkish SMEs. J. Clean. Prod. 2013, 51, 23-33. [CrossRef]

34. Gadenne, D.L.; Kennedy, J.; McKeiver, C. An empirical study of environmental awareness and practices in SMEs. J. Bus. Ethics 2009, 84, 45-63. [CrossRef]

35. Lee, K. Why and how to adopt green management into business organizations? The case study of Korean SMEs in manufacturing industry. Manag. Decis. 2009, 47, 1101-1121. [CrossRef] 
36. Reyes-Rodríguez, J.F.; Ulhøi, J.P.; Madsen, H. Corporate environmental sustainability in Danish SMEs: A longitudinal study of motivators, initiatives, and strategic effects. Corp. Soc. Responsib. Environ. Manag. 2016, 23, 193-212. [CrossRef]

37. Hoogendoorn, B.; Guerra, D.; van der Zwan, P. What drives environmental practices of SMEs. Small Bus. Econ. 2015, 44, 759-781. [CrossRef]

38. Johnson, M.P. Sustainability management and small and medium-sized enterprises: Managers' awareness and implementation of innovative tools. Corp. Soc. Responsib. Environ. Manag. 2015, 22, 271-285. [CrossRef]

39. Sekaran, U.; Bougie, R. Research Methods and Business: A Skilled-Building Approach; John Wiley \& Sons: West Sussex, UK, 2016; ISBN 978-1-119-26684-6.

40. Miles, M.B.; Huberman, A.M. An Expanded Sourcebook: Qualitative Data Analysis; Sage Publications Inc.: London, UK; Thousand Oaks, CA, USA, 1994; ISBN 9780803946538.

41. Sullivan, J.R. Skype: An appropriate method of data collection for qualitative interviews? Hilltop Rev. 2012, 6, 54-60.

42. European Commission. User Guide to the SME Definition. Available online: https://ec.europa.eu/regional_ policy/sources/conferences/stateaid/sme/smedefinitionguide_en.pdf (accessed on 24 February 2020).

43. Eisenhardt, K.M. Building theories from Case Study Research. Acad. Manag. Rev. 1989, 14, 532-550. [CrossRef]

44. Attride-Stirling, J. Thematic networks: An analytic tool for qualitative research. Qual. Res. 2001, 1, $385-405$. [CrossRef]

45. Braun, V.; Clarke, V. Using thematic analysis in psychology. Qual. Res. Psychol. 2006, 3, 77-101. [CrossRef]

46. Nowell, L.S.; Norris, J.M.; White, D.E.; Moules, N.J. Thematic analysis: Striving to meet the trustworthiness criteria. Int. J. Qual. Methods 2017, 16, 1-13. [CrossRef]

47. King, N. Using templates in the thematic analysis of text. In Essential Guide to Qualitative Methods in Organizational Research; Cassell, C., Symon, G., Eds.; Sage: London, UK, 2004; pp. 257-270, ISBN 9780761948872.

48. Longoni, A.; Golini, R.; Cagliano, R. The role of new forms of work organization in developing sustainability strategies in operations. Int. J. Prod. Econ. 2014, 147, 147-160. [CrossRef]

49. Boström, M. A missing pillar? Challenges in theorizing and practicing social sustainability: Introduction to the special issue. Sustain. Sci. Pract. Policy 2017, 8, 3-14. [CrossRef]

50. Jansson, J.; Nordlund, A.; Westin, K. Examining drivers of sustainable consumption: The influence of norms and opinion leadership on electric vehicle adoption in Sweden. J. Clean. Prod. 2017, 154, 176-187. [CrossRef]

51. United Nations. Social Sustainability. Available online: https:/www.unglobalcompact.org/what-is-gc/ourwork/social (accessed on 13 May 2020).

52. Rao, P. Greening the supply chain: A new initiative in South East Asia. Int. J. Oper. Prod. Manag. 2002, 22, 632-655. [CrossRef]

53. Zhu, Q.; Sarkis, J. Relationships between operational practices and performance among early adopters of green supply chain management practices in Chinese manufacturing enterprises. J. Oper. Manag. 2004, 22, 265-289. [CrossRef]

54. Guler, I.; Guillén, M.F.; Macpherson, J.M. Global competition, institutions, and the diffusion of organizational practices: The international spread of ISO 9000 quality certificates. Adm. Sci. Q. 2002, 47, 207-232. [CrossRef]

55. Bansal, P.; Roth, K. Why Companies Go Green: A Model of Ecological Responsiveness. Acad. Manag. J. 2000, 43, 717-736. [CrossRef]

Publisher's Note: MDPI stays neutral with regard to jurisdictional claims in published maps and institutional affiliations.

(C) 2020 by the authors. Licensee MDPI, Basel, Switzerland. This article is an open access article distributed under the terms and conditions of the Creative Commons Attribution (CC BY) license (http://creativecommons.org/licenses/by/4.0/). 